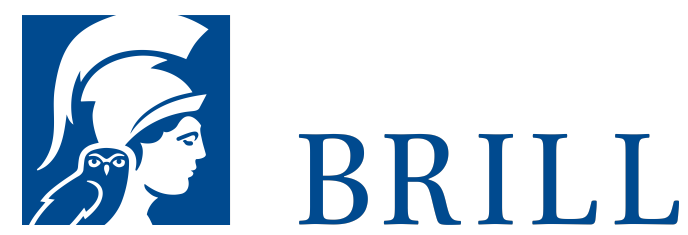

\title{
Choreographie der Herrschaft
}

Stefano della Bellas Radierungen zu den Reiterfesten am Florentiner Hof 1637-1661

Author: Martina Papiro

Der Graphiker Stefano della Bella (1610 - 1664) schuf die Radierungen zu den Reiterfesten des Florentiner Hofs, die der Illustration gedruckter Festbeschreibungen dienten. Solche Auftragswerke waren im 17. Jahrhundert längst etablierte Formen höfischer Repräsentation. Doch della Bellas Radierungen setzten in der Festpublizistik neue Maßstäbe: Erstmals wurden nicht nur die Kostüme und Dekorationen dokumentiert, sondern auch die Aufführungen selbst. Konzept und Choreographie der Reiterfeste fanden auf della Bellas Blättern eine eigenständige künstlerische Umsetzung. Martina Papiro analysiert die Darstellungsstrategien della Bellas und untersucht Kontext, Funktionsweisen und die europaweite Rezeption seiner innovativen Radierungen.

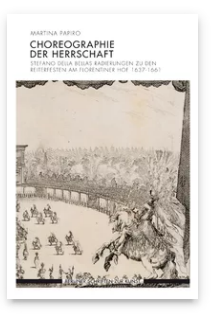

Pages: 491 Seiten, $186 \mathrm{~s} / \mathrm{w}$ und 1 farb. Abb.

Language:

German

Subjects: Art

History, Art

History

Publisher: Brill |

Fink

Series:

Berliner

Schriften zur

Kunst

E-Book (PDF)

Released online: 10 Aug 2020

ISBN: $978-3^{-}$

$8467-5851-9$

List price

Paperback

Publication date: o1 Apr 2016

ISBN: 978-3$7705-5851-3$

List price 
Martina Papiro hat Kunst-, Musik- und deutsche

Literaturwissenschaft in Basel, Berlin und Florenz studiert. Ihre

Dissertation verfasste sie zur Druckgraphik in der Florentiner

Festpublizistik des 16.-17. Jahrhunderts. Ihre

Forschungsschwerpunkte umfassen Verbindungen von Kunst,

Musik und Festkultur in der italienischen frühen Neuzeit.

Zurzeit ist sie freischaffende Kunst- und

Musikwissenschaftlerin, u. a. mit Tätigkeiten als

Ausstellungskuratorin, Übersetzerin und freie Mitarbeiterin bei SRF 2 Kultur.

For more information see brill.com

Order information: Order online at brill.com

+44330 3330049 | customerservices@brill.com

Submission information: brill.com/authors

Titles published by Brill | Fink, Brill | mentis or Brill | Schöningh:

+49(o)71 5413279216 | brill@brocom.de 